\title{
Pilot plant scale evaluation of a commercial yeast nutrient for high test molasses fermentation'
}

\author{
Eduardo Cacho, Nivia Murphy and Eleanor Fontanet
}

\begin{abstract}
A pilot plant nutrient study was performed with fed-batch fermentation mode, $10 \%$ seed inoculum, and the sugar concentration needed to obtain $9 \%(v / v)$ ethyl alcohol using high test molasses. The nutrients consisted of ammonium sulfafe $(2 \mathrm{~g} / \mathrm{L})$, ammonium phosphate $(0.5 \mathrm{~g} / \mathrm{L})$ and yeast nutrient (1 g/L) for treatment 1 , and ammonium sulfate $(2 \mathrm{~g} / \mathrm{L}$ ) for treatment 2. After $\mathbf{2 4}$ hours, samples were analyzed for alcohol yield and congener composition. The additional nufrients for freatment 1 sped up the fermentations and thus increased yields at 24-hour fermentation time.

\section{RESUMEN}

Evaluación a escala de planta piloto de un nutrimento camercial de levadura para fermentar mieles ricas

Se hicieron estudios a escala de laboratorio experimental con un proceso semicontinuo de $10 \%$ de inóculo de levadura y el azúcar necesario para obtener $9 \%(\mathrm{v} / \mathrm{v})$ de etanol. Los nutrimentos añadidos fueron sulfato amónico $(2 \mathrm{~g} / / \mathrm{l})$, fosfato monobásico de amonio $(0.5 \mathrm{~g} . / \mathrm{l}$.) y nutrimento comercial de levadura (1 g./.). Después de 24 horas las muestras se analizaron para medir el rendimiento alcohólico y la composición de congenéricos. La adición de nutrimentos de levadura logró que las fermeniaciones progresaran más rápidamente y produjeran rendimientos más altos.
\end{abstract}

\section{INTRODUCTION}

During fiscal year 1986 the rum industry of Puerto Rico generated $\$ 241.9$ million in excise taxes or $9 \%$ of the insular income (2). Traditionally, the Puerto Riean rum industry has used blackstrap molasses (BM), a by-product of the sugar industry, as raw material because of its availability and price. However, since 1970 the local sugar industry has not been able to supply all the BM the rum industry needs. In 1983 rum producers imported $36,749,724 \mathrm{gal}(1,390,977 \mathrm{hL})$ of $\mathrm{BM}, 94 \%$ of the total used. BM is imported, but some exporting countries are at present in-

IManuseript submitted to Editorial Board 30 October 1987.

"Chemical Engineer, Bacteriologist, Rum Pilot Plant, and Assistant Statistician, Statistics Section, Agricultural Experiment Station, Mayagüez Campus, University of Puerto Rico, Rio Piedras, P. R. 
creasing their rum production to take advantage of the recently relaxed U.S. tariff barriers.

The Rum Pilot Plant has been working since 1979 on possible alternatives to BM as raw material which could be produced locally and thus eliminate the need for outside sources. Emphasis has been placed on methods for the production and evaluation of high test molasses (HTM). HTM is defined as a clarified sugarcane syrup, partially inverted to avoid crystalization, and evaporated to ca $85^{\circ}$ Brix. A procedure for manufacturig HTM was developed at the Rum Pilot Plant (8), and for the past 5 years comparative studies of HTM and BM have concentrated on nutrients, rate of fermentation, congener generation, characterization of slops and aging of distillates $(3,4,7,10)$. These studies have demonstrated that there are significant differences between HTM and BM in many aspects of rum manufacture.

A statistical comparison of HTM and BM to pilot plant scale (1) determined that fermentation rates were slower for HTM fermentation, thus requiring a longer fermentation time to achieve the conversion from sugar to alcohol. Longer fermentation times result in higher operating costs for the rum industry, so it is desirable to minimize fermentation time for HTM fermentations. Previous laboratory scale studies had determined the desirability of nutrients for this purpose $(4,5)$ so a study using commercial grade nutrients including Yeastex $61^{3}$, ammonium phosphate, and ammonium sulfate was performed in pilot plant scale, The levels of nutrient used were based on laboratory scale studies (5).

Yeastex 61 is a commercial preparation by Scott Laboratories, Inc., which has been approved for use in wineries by the U.S. Bureau of Alcohol, Tobacce \& Fire Arms. It is a mixture of mineral salts and organic nutrients essential for vigorous yeast growth, with important trace elements, amino acids and other growth factors. Similar preparations are available from other companies.

\section{MATERTALS AND METHODS}

Equipment

Fermentations were carried out in 3,785 L (working capacity) tanks with covered tops to achieve anaerobic conditions. These tanks were equipped with a 2-inch diameter outlet for the $\mathrm{CO}_{2}$ generated, a $65-\mathrm{ft}^{2}$ surface area coil for cooling water, a sight gage for measuring liquid level, a thermometer, and 1.5-hp centrifugal pump for recirculating the fermenting broth. We added the molasses mash at a constant rate by

${ }^{3 T}$ Trade names are used solely for the purpose of providing specific information. Mention of trade names does not constitute a guarantee or warranty by the Agricultural Experiment Station of the University of Puerto Rico or an endorsement over other preparations not mentioned. 
pumping from a $1900-\mathrm{L}$ (working capacity) tank with a $3 / 4$-hp variable speed drive. Flow rate was adjusted manually and measured with a rotameter. The molasses mash and fermented broth were centrifuged with a Westfalia Separator Model NS-7-06-076. Distillation was performed with the Rum Pilot Plant Beer Column. Except for the distillation column, all materials of construction in direet contact with the molasses mash or broth were of type 316 stainless steel.

\section{Experimental procedures}

Initially, all the equipment was sterilized with live steam. The molasses feed consisted of a $50 \mathrm{~g} / 100 \mathrm{ml}$ fermentable sugar solution. It was pasteurized at $77^{\circ} \mathrm{C}$ for $45 \mathrm{~min}$ and then cooled to $30^{\circ} \mathrm{C}$ with water through the internal coil heat exchanger. We prepared the yeast inoculum by scaling up the procedures used in the laboratory scale studies (4). Yeast cell count was determined on a Neubauer Hemacytometer.

The fermentor was first charged with $2,536 \mathrm{~L}$ of tap water; subsequently, $378 \mathrm{~L}$ of yeast inoculum was added, followed by $871 \mathrm{~L}$ of molasses mash, which was added at a constant rate of $54.5 \mathrm{~L}$ per hour in $16 \mathrm{~h}$. The final volume for all the runs was $3785 \mathrm{~L}$. The nutrients (which were added to both the inoculum tank and fermentor) consisted of ammonium sulfate $(2 \mathrm{~g} / \mathrm{L})$, ammonium phosphate $(0.5 \mathrm{~g} / \mathrm{L})$ and Yeastex $61(1 \mathrm{~g} / \mathrm{L}$ ), for treatment $\mathrm{l}$ (four runs), and $2 \mathrm{~g} / \mathrm{L}$ of ammonium sulfate for treatment 2 (four runs). Throughout the fermentations the recirculating pump was running and the temperature in the fermentor was kept at ca $30^{\circ} \mathrm{C}$ with cooling water through the inner coil. All experiments ran for 24 hours. Samples were drawn every 4 hours. We added $2 \mathrm{~g} / \mathrm{L}$ of mercuric chloride to the samples to stop the fermentation. To monitor the process, we analyzed samples for total sugars $(\mathrm{g} / 100 \mathrm{ml})$, alcohol percentage $(\mathrm{v} / \mathrm{v})$, total acidity $(\mathrm{g} / \mathrm{L})$, and $\mathrm{pH}$. The 24 -hour samples were also analyzed for congeners composition (3). Methods for the analyses are described in the Official Methods of the Rum Pilot Plant (6). Subsequently, the fermentation broth was centrifuged and then distilled. To keep interfering variables to a minimum, we based the statistical studies on the 24-hour samples before centrifugation and distillation.

The yield percentage was calculated by stoichiometry; the expected alcoholic yield was $9 \%$ by volume. Results were analyzed with analysis of variance to ascertain the significance $(p=0.05)$ of the differences between the two treatments (9).

\section{RESULTS AND DISCUSSION}

Table 1 presents the average results of the analysis at $24 \mathrm{~h}$ fermentation time. Also included are the inoculum cell count, initial total acidity, and yield percentage (stoichiometric). 
TABLE 1.-Inoculum cell connt, initial total acidity, final composition ( $24 \mathrm{~h}$ ) ineluding congeners and yield percentage at different nutrient levels, averages for treatment 1 and treatment 2

\begin{tabular}{|c|c|c|}
\hline \multirow[b]{2}{*}{ Variables } & \multicolumn{2}{|c|}{ Nutrient Levels } \\
\hline & 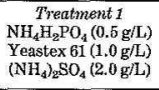 & $\begin{array}{c}\text { Treatment } 2 \\
\left(\mathrm{NH}_{4}\right)_{2} \mathrm{SO}_{4}(2.0 \mathrm{~g} / \mathrm{L})\end{array}$ \\
\hline & \multicolumn{2}{|c|}{ Ohours } \\
\hline $\begin{array}{l}\text { Inoculum cell count } \\
\text { (millions } / \mathrm{ml} \text { ) }\end{array}$ & $251 \mathbf{a}^{2}$ & 284 a \\
\hline \multirow[t]{2}{*}{ Initial total acidity $(\mathrm{g} / \mathrm{L})$} & $1.2 \mathrm{a}$ & $1.2 \mathrm{a}$ \\
\hline & \multicolumn{2}{|c|}{24 hours } \\
\hline Final total acidity $(\mathrm{g} / \mathrm{L})$ & $5.0 \mathrm{a}$ & $4.1 \mathrm{~b}$ \\
\hline Residual sugar (g/100ml) & $1.0 \mathrm{a}$ & $2.9 \mathrm{~b}$ \\
\hline Ethyl alcohol (\% volume) & $7.1 \mathrm{a}$ & $6.0 \mathrm{~b}$ \\
\hline$\%$ Yield (\% of theoretical) & $75.2 \mathrm{a}$ & $62.3 \mathrm{~b}$ \\
\hline \multicolumn{3}{|c|}{ Congeners (mg/100 $\mathrm{ml}$ at $\left.80^{\circ} \mathrm{P}\right)$} \\
\hline acetaldehyde & $9.2 \mathrm{a}$ & $19.2 \mathrm{a}$ \\
\hline methyl acetate & $7.5 \mathrm{a}$ & $0.0 \mathrm{~b}$ \\
\hline ethyl acetate & $18.9 \mathrm{a}$ & $22.9 \mathrm{a}$ \\
\hline acetal & $0.0 \mathrm{a}$ & $0.0 \mathrm{a}$ \\
\hline n-propyl aleohol & $41,4 \mathrm{a}$ & $81.9 \mathrm{~b}$ \\
\hline isobutyl alcohol & $22.3 \mathrm{a}$ & $17.6 \mathrm{a}$ \\
\hline isoamyl acetate & $0.0 \mathrm{a}$ & $0.0 \mathrm{a}$ \\
\hline n-butyl alcohol & $2.6 \mathrm{a}$ & $0.0 \mathrm{a}$ \\
\hline isoamyl alcohol & $18.7 \mathrm{a}$ & $24.3 \mathrm{a}$ \\
\hline n-amyl alcohol & $0.3 \mathrm{a}$ & $19.0 \mathrm{a}$ \\
\hline Total & $120.9 \mathrm{a}$ & $134.9 \mathrm{a}$ \\
\hline esters & $26.4 \mathrm{a}$ & $22.9 \mathrm{a}$ \\
\hline fusel & $85.3 \mathrm{a}$ & $92.8 \mathrm{a}$ \\
\hline
\end{tabular}

Means in the same row followed by one letter in common do not differ significantly at the $5 \%$ probability level.

Average yield percentage was higher for treatment 1 ( 75.2 vs. 62.3 ). This difference was significant. Figure 1 shows that there was a steeper slope for the logarithmic phase for treatment 1 fermentations, a fact which is responsible for higher yields. Since the yield is a measure of alcohol generated vs. sugar consumed, it is consistent that residual sugar (1.0 vs. 2.9 ) and alcohol (7.1 vs. 6.0 ) are also significantly different.

Although the initial total acidity was not significantly different for the two treatments, the final total acidity showed a significant difference (5.0 vs. 4.1). This result could be accounted for by the gradual release of organic acids by the yeast during fermentation, inasmuch as treatment 1 was in a more advanced stage of fermentation, or could be due to the 


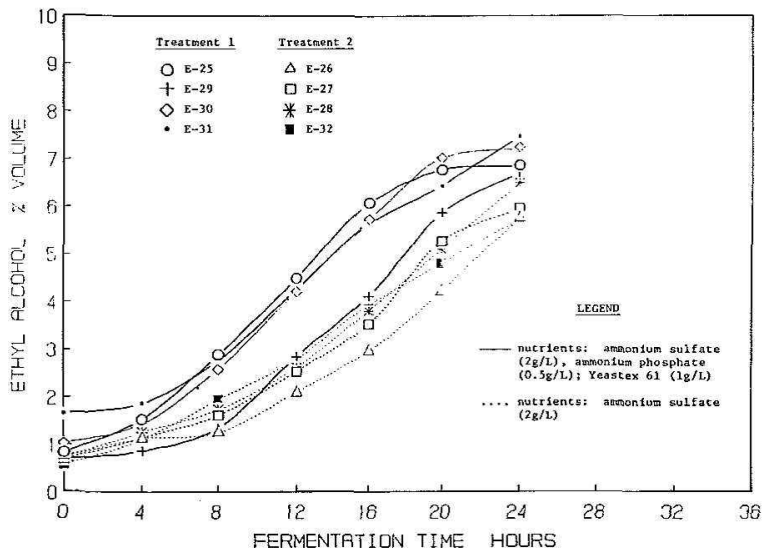

FiG. 1-Ethyl alcohol as a function of time for high test molasses fermentation at different nutrient levels.

nutrients per se. No definite conelusion could be made with the data available.

From the average figures we could say that the congener generation was more favorable for runs with all nutrients: lower total congeners (120.9 vs. 134.9 ), higher ester (26.4 vs. 22.9 ), lower fusel ( 85.3 vs. 92.8 ); however, these differences were not statistically significant.

The congeners that showed significant differences were methyl acetate with an average of $7.5 \mathrm{mg} / 100 \mathrm{ml}$ at $80^{\circ} \mathrm{P}$, and no reading in treatments 1 and 2, respectively; and n-propyl alcohol with averages of 41.4 and 31.9 in treatments 1 and 2 , respectively.

We can conclude that Yeastex 61 and ammonium phosphate improved high test molasses fermentation performance and consistently sped up fermentation rates without altering the total congener, esters and fusel content.

\section{LITERATURE CITED}

1. Cacho, E., N. F. Murphy and E. Fontanet. Pilot plant fermentation of high test molasses compared with blackstrap molasses using factorial design, J. Agric. Univ. P. R. 72 (1): 9-17.

2. Custodio, P. G., 1987. Informe Económico del Gobernador 1986. Junta de Planificación de Puerto Rico. 
3. Martinez, G. and N. Murphy, 1984. Congeners from high test molasses alcoholic fermentation, J. Agric. Univ. P. R. 68 (1); 59-66.

4. Murphy, N., 1984. Fermentation of high test molasses, J. Agrie. Univ. P. R. 68 (1): 33-44.

5. Murphy, N. F. and E. Cacho, 1987. Evaluation of a commercial yeast nutrient for high test molasses fermentation. J. Agric. Univ. P. R. 72 (1): 173-76.

6. Official Analytical Methods of the Rum Pilot Plant, 1969. Agric. Exp. Stn., Univ. P. R. Río Piedras, P. R.

7. Ramírez, M., 1982. Characterization of slops of high test molasses alcoholie fermentation, J. Agric. Univ. P. R., 66 (3): 235-37.

8. Rosado, E., 1982. Método para la elaboración de melaza riea, No. $23-83$. Rum Pilot Plant, Agxic. Exp. Stn. Univ. P. R., Rio Piedras, P, R.

9. Steel, L. R. and Torrie, J., 1960. Principles and Procedures of Statistics, MeGrawHill, p. 76.

10. Torres, C. S., Z, de Ayala and M. I. Rivera, 1987. Aging of high test molasses rums. J. Agrie. Univ. P. R. 71 (2): 137-58. 